\section{Bargaining in institutionalized settings: The case of Turkish reforms}

European Journal of International Relations 16(3) 463-483

(C) The Author(s) 2010 Reprints and permissions: sagepub. co.uk/journalsPermissions.nav DOI: I0.1 I77//354066/09344009 ejt.sagepub.com

\author{
Zeki Sarigil \\ Bilkent University, Ankara, Turkey
}

\begin{abstract}
By analyzing the case of a bargaining situation in an institutionalized setting, which derives from Turkey's reform process in a sensitive issue area (civil-military relations), this study assesses the explanatory power of competing models of bargaining: rational, normative, and discursive/argumentative. The bargaining outcome in this case was puzzling because despite the existence of a strongly pro-status quo veto player (i.e. the military), the bargaining processes led to a new status quo.This study shows that the veto player simply failed to prevent a shift to a new status quo because such an action would do substantial damage to the military's ideational concerns (normative entrapment). The rational model remains under-socialized, while the discursive model is over-socialized in analyzing this bargaining situation. Although the normative model sheds more light on this puzzling outcome, a synthesis between normative and rational models would provide us with much better insight.
\end{abstract}

\title{
Keywords
}

bargaining, civil-military relations, normative entrapment, veto player

\section{Introduction}

Bargaining is a quite common phenomenon in the political world. As has been suggested, most conflict situations are essentially bargaining situations (Schelling, 1963). As a result, since Thomas Schelling introduced the first systematic theorizing about bargaining in the early 1960s, bargaining has been one of the most studied political phenomena in political science. That said, we see competing models of bargaining in the field, such as rational, normative, and argumentative/discursive. Rational models view bargaining as a strategic action and emphasize material interests, instrumental rationality, and bargaining strength based on material resources in analyzing bargaining processes and outcomes (Ensminger and Knight, 1997, 1998; Fearon, 1994; Moravcsik, 1993). For the second model, bargaining

\footnotetext{
Corresponding author:

Zeki Sarıgil, Department of Political Science, Bilkent University, 06800, Biillkent, Ankara-Turkey

Email: sarigil@bilkent.edu.tr
} 
is a symbolic, norm-guided interaction, and ideational concerns and rule-following behavior are key features of bargaining situations (Elgström and Jönsson, 2000; Lewis, 2003; Müller, 2004). Finally, the argumentative/discursive model pays more attention to the role of truthseeking, discursive interaction, and persuasion by the 'better argument' as the defining factors in bargaining processes (Joerges and Neyer, 1997; Risse, 1999, 2000, 2004).

The main goal of this article is to gauge the explanatory power of these competing models of bargaining by analyzing bargaining situations in institutionalized settings, where bargaining processes take place in the presence of formal and informal rules, norms, values, and audience, and cases where at least one veto player strongly defends the status quo in a sensitive issue area, involving high stakes for actors. Analyzing such 'hard' cases would provide more convincing evidence for our efforts to assess the relative strength of these distinct models of bargaining.

The case analyzed in this study derives from the reform process in Turkey in a sensitive issue area: civil-military relations. For two main reasons, this case provides a good laboratory in which to investigate the relative utility of these bargaining models. First, bargaining took place in a normatively institutionalized environment in the sense that bargaining processes took place in a democratic polity in the public sphere. In addition, bargaining was about changing the institutional status quo (i.e. changing the functions and composition of the National Security Council — Milli Güvenlik Kurulu; MGK). Analyzing such a bargaining situation would enable us to look at whether the existing social-normative context has any impact on bargaining processes. Second the veto player (the military) strictly defended the status quo. However, it is puzzling that despite the existence of a strongly pro-status quo veto player, the bargaining processes led to a new status quo in Turkish civil-military relations, increasing civilian control of the military. Thus, the research puzzle is why the pro-status quo veto player accepted a bargaining outcome that was contrary to its initial position. Which model, rational, normative, or discursive, can explain this outcome better?

\section{Findings/arguments}

This study argues that the veto player in the aforementioned bargaining situation simply failed to prevent a shift to a new status quo because such an action would do substantial damage to its ideational concerns (i.e. loss of legitimacy, credibility, and prestige in the public sphere for being an obstacle to Turkey's century-old Westernization efforts). This study suggests that both the argumentative and rational models alone fail to explain this outcome. The argumentative model remains limited in explaining it because, as will be shown below, communicative processes did not result in persuasion during these bargaining processes. Although neither side persuaded the other side during bargaining, significant changes took place despite the existence of a strictly pro-status quo veto player. The reason for the failure of the rational model is that with its focus on instrumental rationality, strategic action, and material interests, this unidimensional model remains limited for analyzing bargaining situations in institutionalized settings, which should be understood not only as strategic competition over material benefits but also as a normguided social process. Thus, the rational model remains under-socialized, while the discursive model is over-socialized, exaggerating the level of truth-seeking behavior and persuasion during bargaining. As will be shown below, the normative model provides a 
better explanation and understanding of this bargaining situation. That having been said, in order to fully understand bargaining processes in institutionalized settings, which involve both strategic and normative dynamics and factors, a synthesis between rational and normative models would provide us with much better insight.

The article proceeds as follows. The theoretical part briefly presents the arguments of rational, normative, and argumentative models of bargaining and draws some hypotheses. The following case study section investigates the empirical plausibility of the theoretical arguments. This section first introduces the outcome of bargaining in the reform process in civil-military relations in Turkey. Then, it analyzes the bargaining outcome from the perspective of three models of bargaining and assesses the explanatory powers of each model. The concluding section restates the main arguments of the study and responds to some possible counterarguments.

\section{Rational, normative, and argumentative models and hypotheses}

Bargaining has been defined as 'a process in which explicit proposals are put forward ostensibly for the purpose of reaching agreement on an exchange or on the realization of a common interest where conflicting interests are present' (Iklé, 1964: 3-4; see also Elgström and Smith, 2000: 674). This shared definition suggests that a bargaining situation should be characterized by interdependence and the existence of common and competing interests (Elgström and Smith, 2000: 674; Schelling, 1963: 3).

In the existing literature, the terms bargaining and negotiation are sometimes conflated. However, it is also suggested that bargaining is a 'broader concept, including exchange of verbal as well as non-verbal communication, formal as well as informal exchanges' (Jönsson and Elgström, 2005: 2). Thus, bargaining processes might take explicit or tacit forms. In the case of tacit bargaining, bargainers 'watch and interpret each other's behaviors' rather than explicitly communicating in formal settings (Schelling, 1963: 21). Negotiation, on the other hand, is treated as a subclass of bargaining, which refers to 'structured, verbal bargaining' (Doron and Sened, 2001; Jönsson and Elgström, 2005: 2). Without making such a distinction, some studies treat bargaining and arguing as two different modes of negotiation or communication (see Risse, 2004).

Since this study analyzes interactions in institutional environments in the domestic realm, where both formal and informal exchanges take place, the term bargaining is preferred and arguing is treated as a distinct mode of bargaining. Table 1 presents three different models of bargaining. These models should be treated as ideal types, which may not necessarily exist in pure forms in the political world. In addition, they are analytically distinct models of bargaining but they might operate simultaneously in real bargaining situations. ${ }^{1}$ This work is primarily concerned with the question of which one of these theoretical lenses captures more of bargaining processes and outcomes in institutionalized settings.

\section{Rational model}

According to the rational model, the main motivation of actors in bargaining situations is to maximize material interests derived from an individual-level cost-benefit calculation 
Table I. A comparison of three models of bargaining

\begin{tabular}{|c|c|c|c|}
\hline & Rational & Normative & Argumentative/discursive \\
\hline Motivations & $\begin{array}{l}\text { Material interests } \\
\text { (e.g. power, wealth, } \\
\text { security) derived from } \\
\text { individual-level cost- } \\
\text { benefit calculations } \\
\text { (exogenous) }\end{array}$ & $\begin{array}{l}\text { Ideational concerns } \\
\text { (e.g. legitimacy, } \\
\text { reputation, prestige, } \\
\text { and self-realization) } \\
\text { shaped by social } \\
\text { context (endogenous) }\end{array}$ & $\begin{array}{l}\text { Truth-seeking, } \\
\text { reasoned consensus } \\
\text { or common } \\
\text { understanding } \\
\text { (endogenous) }\end{array}$ \\
\hline Process & $\begin{array}{l}\text { Strategic interaction } \\
\text { involving issue linkages, } \\
\text { side payments, credible } \\
\text { threats }\end{array}$ & $\begin{array}{l}\text { Symbolic/normative } \\
\text { interaction involving } \\
\text { various (de)legitimation } \\
\text { processes }\end{array}$ & $\begin{array}{l}\text { Discursive interaction } \\
\text { (argumentative and } \\
\text { discursive processes) }\end{array}$ \\
\hline $\begin{array}{l}\text { Rationality/ } \\
\text { logic }\end{array}$ & $\begin{array}{l}\text { Instrumental (logic of } \\
\text { consequentiality) }\end{array}$ & $\begin{array}{l}\text { Social/collective (logic } \\
\text { of appropriateness) }\end{array}$ & $\begin{array}{l}\text { Communicative (logic of } \\
\text { arguing) }\end{array}$ \\
\hline $\begin{array}{l}\text { Determining } \\
\text { factors }\end{array}$ & $\begin{array}{l}\text { Bargaining power, } \\
\text { lowest common } \\
\text { denominator }\end{array}$ & $\begin{array}{l}\text { Rule-following/norm } \\
\text { compliance }\end{array}$ & $\begin{array}{l}\text { Persuasion by the 'better } \\
\text { argument' }\end{array}$ \\
\hline Style & Hard bargaining & $\begin{array}{l}\text { Integrative } \\
\text { bargaining }\end{array}$ & Integrative bargaining \\
\hline
\end{tabular}

(Bazerman and Neale, 1992: 1; Brams, 1990; Doron and Sened, 2001). The bargaining process is simply a strategic interaction in which actors use strategies such as issue linkage, side payments, and credible threats to achieve their exogenously given material interests (Fearon, 1994; Moravcsik, 1993; Putnam, 1988; Riker, 1962; Schelling, 1963). Instrumental rationality (the logic of consequentiality) is the dominant rationality within this process. Actors choose the most effective means to realize their given interests. Relative power has a determinative effect on bargaining outcomes that usually reflect the lowest common denominator (see Ensminger and Knight, 1997, 1998; Knight, 1992; Knight and Sened, 2001; Moravcsik, 1993). Finally, the dominant bargaining style in this model is hard bargaining (Fearon, 1998; Moravcsik, 1993; Scharpf, 1988), in which the goal of actors is to win at the expense of the other party (Hopmann, 1995: 33). Thus bargaining, according to the rational model, also known as distributive bargaining (Walton and McKersie, 1965: 4-5), is a conflictual, strategic process based on self-interest (Elgström and Jönsson, 2000: 685).

\section{Normative model}

The normative model derives from the constructivist approach, which asserts that the world is not only made of material factors but also ideational factors such as norms, values, identities, and beliefs. Therefore, individuals do not interact in a technical, material world but in a socio-cultural environment. In such a social environment, actors are also motivated by their ideational concerns such as legitimacy, reputation, and prestige in the institutional environment (Avant, 2000: 48; Hall, 1993: 46-9; March and Olsen, 1989). However, it is argued that rational models neglect the social-normative context of bargaining (see Bjurulf and 
Elgström, 2005; Lewis, 1998: 480, 2003: 105; Schoppa, 1999). Kramer and Messick, who treat bargaining as 'a social process,' state that the rationalist literature on bargaining:

... lost sight of negotiation as a form of social action, given meaning by certain structural contexts. ... At most, social factors were deemed irrelevant. At worst, they constituted annoying sources of extraneous and uncontrolled variation in empirical investigations. (1995: viii)

Thus the normative model emphasizes the impact of social context on the bargaining process, which plays an independent causal role in bargaining situations (see Elgström, 2005; Elgström and Jönsson, 2000; Elgström and Smith, 2000; Kramer et al., 1993; Lewis, 2003: 108; Müller, 2004). In an institutional environment, actors are not only homo economicus but also homo sociologicus in the sense that actors also act on the basis of institutionalized collective understandings such as shared ideas, norms, and values (Barnett, 1998: 9; Goffman, 1969: 43). These collectively shared intersubjective understandings not only regulate behavior but also constitute actors' identities and consequently their interests and interactions (Adler, 1997; Checkel, 1997; Finnemore and Sikkink, 1998; Katzenstein, 1996: 5; Klotz, 1995: 13-35; Lewis, 2003; Wendt, 1999). Therefore, actors are also expected to follow rules and norms and do 'the appropriate thing' rather than just maximizing their exogenously defined interests. ${ }^{2}$

For the normative model, the nature of interactions in bargaining processes is primarily symbolic, involving complex legitimation and delegitimation processes. Interests are endogenous to the social interaction because actors learn or are socialized into new ideas and beliefs. As a result of these interactions, they redefine their interests. The determining factor in this model is norm compliance and rule-following rather than bargaining power (see Høgsnes, 1989; Kahneman et al., 1987). Finally, the main bargaining style for this model is integrative (also known as principled negotiation - Fisher et al., 1991 - and problem solving - Hopmann, 1995). Compared to hard bargaining, actors in integrative bargaining have much more cooperative attitudes and are more concerned with common interests (i.e. being concerned with reaching pareto-optimal solutions; Elgström and Jönsson, 2000: 685; Walton and McKersie, 1965) and with 'the appropriate thing.'

\section{Discursive/argumentative model}

Finally, for the third model of bargaining, which is derived from Jürgen Habermas's theory of communicative action, actors are primarily motivated by truth-seeking, common understanding, or reasoned consensus (Verständigung) rather than maximizing or satisfying their given, fixed interests or preferences (Risse, 2000: 7, 2004: 294). According to this model, bargaining cannot be reduced to the exchanges of demands, threats, and promises but is primarily a process based on deliberative and truth-seeking behavior. Through argumentation, actors use 'reasons' in order to persuade others of the validity and the justifiability of their claims (Elster, 1991).

This model suggests that since communication forms an important part of any bargaining process (Jönsson, 1990: 2; Risse, 2000), the nature of bargaining is discursive rather than normative or strategic (Joerges and Neyer, 1997; Risse, 1999: 532). Within this discursive process, 'argumentative and discursive processes challenge the truth 
claims inherent in identities and perceived interests' (Risse, 1999: 530). In other words, actors' interests, preferences, and the perceptions of the situation are not fixed during the bargaining process. Rather, interests are subject to interrogation and discursive challenges (Risse, 2000: 7). In the words of Risse (2000: 10), 'Interests and identities are no longer fixed, but subject to interrogation and challenges and, thus, to change. The goal of the discursive interaction is to achieve argumentative consensus with the other, not to push through one's own view of the world or moral values. ${ }^{3}$ The dominant rationality in such discursive processes, the model claims, is communicative rationality (the logic of arguing), based on 'argumentation' and 'persuasion.' The determining factor in the bargaining process is the 'better argument' rather than relative bargaining power based on material resources or norm-following behavior. Finally, the bargaining style in this model is integrative (see Risse, 1999, 2000, 2004, for more discussion on this model).

\section{Hypothetical expectations of bargaining in institutionalized settings}

What would each of these models tell us about bargaining situations in institutionalized settings, in which a veto player strictly defends the status quo in a sensitive issue area? According to one rationalist argument, institutions extend the shadow of the future by regularizing interactions and facilitating the information flows and monitoring. In other words, in an institutional environment it is more likely that actors will interact again in the future. This reciprocity function may facilitate cooperation in bargaining situations in institutional environments (see Axelrod, 1984). In an influential study, Fearon, however, suggests that such a function of institutions may also reduce the chances for cooperation in bargaining situations. He states that:

... though a long shadow of the future may make enforcing an international agreement easier, it can also give states an incentive to bargain harder, delaying agreement in hopes of getting a better deal. For example, the more an international regime creates durable expectations of future interactions on the issues in question, the greater the incentive for states to bargain hard for favorable terms, possibly making cooperation harder to reach. The shadow of the future thus appears to cut two ways. Necessary to make cooperative deals sustainable, it nonetheless may encourage states to delay in bargaining over the terms. (1998: 270-1; emphasis in original)

Thus, according to Fearon, institutions might make enforcing an institutional agreement easier but since actors would live with that institutional equilibrium for a long time, they also have a strong incentive to bargain harder in the first step. This should be even more valid for veto players, actors whose approval is necessary for a shift to a new status quo (see Tsebelis, 2002). Therefore, veto players have a significant degree of power in bargaining situations. Thus, since the rational model suggests that bargaining power shapes the bargaining processes and outcomes, it should be expected that when a veto player prefers the status quo, it would be almost impossible to shift to a new status quo (Scharpf, 1988). This line of arguments leads us to the following straightforward rational hypothesis about bargaining situations in an institutional environment:

$H_{1}$ : If a veto player prefers the status quo to its alternative in a bargaining situation, then the status quo would be the outcome. 
The normative model, on the other hand, would look at whether there is any contradiction between the position of a pro-status quo veto player and predominant norms and ideals in a given institutional environment. Such a discrepancy would constrain the veto player because, as the model suggests, actors in an institutional environment value legitimacy and prestige. Thus, this model would expect that:

$H_{2}$ : The more the position of the pro-status quo veto player contradicts the predominant norms and ideals in the institutionalized setting, the less likely it is that the bargaining outcome will be the lowest common denominator.

Finally, for the discursive model, the determining factor in bargaining situations is 'persuasion by the better argument.' In other words, the relative power of the arguments matter more than the distribution of material capabilities. From this perspective, actors formulating 'better arguments' would have a better chance of shaping bargaining processes and outcomes. Thus one discursive/argumentative hypothesis would be:

$H_{3}$ : If a veto player prefers the status quo to its alternative in a bargaining situation, then change requires the persuasion of that veto player by the 'better arguments' of pro-change actors.

\section{Case study: Reforming Turkish civil-military relations}

In this section, I analyze the case of a bargaining situation that derives from the Europeanization process in Turkey in the early 2000s. Since Turkey was recognized as a candidate state for EU membership during the European Council Helsinki Summit in 1999, Turkish governments have achieved significant constitutional, legislative, and institutional changes in the post-Helsinki era. Terms such as momentous shift (Magen, 2003: 31); revolutionary (Diez, 2005: 168; Oran, 2005: 112; Vardar, 2005: 87); unthinkable (Kubicek, 2005: 362); profound (Öniş, 2003: 13); sweeping (Müftüler-Baç, 2005: 27); impressive (Aydın and Keyman, 2004: 1); unprecedented (Moustakis and Chaudhuri, 2005; Tocci, 2005: 73); and drastic transformation (Kirişçi, 2005) have been commonly used in the media and within academic circles to define this comprehensive reform process. ${ }^{4}$ However, a stark bargaining process between pro-status quo and pro-change actors preceded these reforms. The focus of this section will be on bargaining processes over changes in a sensitive issue area in Turkish politics: civilmilitary relations. Since the explanatory models have many variables but there is only one case, the goal of this study is modest. Rather than testing the explanatory power of the different theoretical models of bargaining presented above, this study, as a plausibility probe, aims to assess the validity and utility of those models in analyzing bargaining situations in institutionalized settings. 5

\section{Reforming civil-military relations}

The strong influence of the military on civilian politics has been a noted characteristic of Turkish politics (Ahmad, 1993: 1; Demirel, 2003; Hale, 2003: 119; Sakallığlu, 1997; Salt, 1999). Although the military still exerts significant influence on civilian politics, substantial changes have taken place in civil-military relations in the post-Helsinki era, which 
reduced the political power of the Turkish military (see also Aydınlı et al., 2006; Güney and Karatekelioğlu, 2005; Sarıgil, 2007).

The MGK, which was established by the 1961 Constitution, has been the most important institutional channel for the military to play its political role (Heper and Güney, 2000: 637; Jenkins, 2001: 7). The military considered the MGK a legal platform from which to articulate its views on all matters of security. After each military intervention, the MGK increased the number of its military members and its own powers (Harris, 1988: 188). However, the existence of such a military-dominated body with a significant degree of executive powers on several issues (e.g. the economy, financial markets, banks, privatization, and foreign policy) created a political system with double executives: the civilian authority (Council of Ministers and the Parliament) and the military authority (the military-dominated MGK) (Gürbey, 1996: 13; Sakallığlu, 1997: 158). This was a direct violation of the norm of democratic control of the armed forces, an important requirement in liberal democracies.

The Seventh Harmonizing Package (July-August 2003) brought fundamental changes to civil-military relations in post-Helsinki Turkey, increasing civilian control of the military. As Öniş and Yılmaz state: 'The seventh harmonizing package represents a major turning point in Turkey-EU relations because for the first time, the political leadership in Turkey found itself in a position to tackle the thorny question of civil-military relations' (2005: 277). For some observers, this reform package represents a revolution in Turkish civil-military relations (Salmoni, 2003). The main goal of this package was to curb the political powers of the military by reforming the MGK. This legislative reform brought fundamental changes to the duties, functioning, and composition of the MGK. The following specific changes were made to the Law of the MGK and the Secretariat-General of the MGK (Law No: 2945):

- The executive and supervisory powers of the Secretary-General of the MGK were eliminated and the MGK itself was reduced to an 'advisory/consultative body.' The main task of the Secretary-General was redefined as secretariat duties in the MGK. It can no longer conduct national security investigations on its own initiative nor can it directly manage the special funds allocated to it.

- The right of the MGK of access to any public body was removed.

- Previously, the Secretary General of the MGK used to be a high-ranking military official. The new secretary is no longer a military official, but a civilian nominated by the Prime Minister and appointed by the head of state.

- The frequency of MGK meetings was also changed. The Council used to meet once a month. In the new regime, the MGK meetings would take place every two months.

- Furthermore, the transparency of the military and defense expenditures was enhanced. Parliamentary scrutiny over military spending through the Court of Auditors was increased. This oversight was expanded by a February 2004 regulation enabling the Court of Auditors, upon the request of the Parliament, to audit accounts and transactions of all types of organizations including the state properties owned by the military.

This crucial reform was a result of intense bargaining between civilians and the military. The government run by the Adalet ve Kalkınma Partisi (Justice and Development 
Party, AKP), which is an offshoot of the banned Islamist Refah Partisi (Welfare Party, 1983-98) and Fazilet Partisi (Virtue Party, 1997-2001), strongly supported the reform because the reform package would simply empower the conservative government vis-avis the strictly secular military. As indicated above, the military-dominated MGK had executive powers on several issues, creating a political system with double executives. Therefore, the civilianization of the MGK and the removal of its executive powers would empower the civilian government. As a result, the government supported the reform package and argued that the reform would be a significant step forward in Turkey's Westernization (i.e. Europeanization) and democratization process.

With respect to the military's position, one can argue that Turkey's EU membership would tie Turkey to a secular and democratic Western bloc. This, in return, would constrain political Islam in Turkey, which has been an important concern for the strictly secular, pro-Western military. Therefore, one could expect that the military would support the MGK reform, which was an important step in fulfilling EU demands. This is a fair argument, but such arguments cannot explain the strong objection of the military to the reform. The military was quite uncomfortable with the reform (Kirişçi, 2005; Magen, 2003: 61) because the MGK reform would curb the military's political powers and constrain the military in its dealings with other political actors. As a result, high-ranking military officials had strong reservations about the reform and harshly criticized the government (Heper, 2005: 38-9). In other words, the military was reluctant 'to relinquish its "sovereignty" over key areas of policy that would directly undermine its privileged positions or interests' (Öniş, 2003: 11). During the debates in the Parliament's Constitutional Commission over the draft law, Mustafa Ağaoğlu, who attended the Commission on behalf of the Secretary-General of the MGK, expressed the reservations of the military in the following way:

[With the suggested reform] ... the MGK Secretariat-General is effectively abolished. It will no longer be able to fulfill these three functions: It will not be able to devise psychological operation plans; it will not be able to work on National Security Policy; it will not be able to devise plans on mobilization and war preparations. The MGK Secretariat-General is attached to the Prime Minister's Office. If the prime minister assigns it a task, it will fulfill it. Other than that, it never undertakes tasks on its own. How will decisions made at the MGK be followed to make sure that they are implemented? (Turkish Daily News, 1 August 2003)

The military, together with the secular, republican, bureaucratic political establishment, perceived the AKP as a 'pro-Islamist and fundamentalist political party' (Coşar and Özman, 2004: 65). Having such a perception of the AKP, the strictly secular military was suspicious of the motivations of the MGK reform initiated by the AKP government. The military disagreed that it was a necessary, urgent step to reform the Council in the EU accession process. Rather, the military believed that the 'pro-Islamic' AKP was taking advantage of the accession process to limit the role of the military within the political system. ${ }^{6}$

However, despite strong opposition from generals, the draft law was accepted by parliament and approved by the head of state. Thus, although the reform package significantly reduced the political powers of the military, the military acquiesced to the reform package (Kirişçi, 2005). This outcome is puzzling because as students of Turkish civil-military 
relations indicate, unlike any other NATO military, the Turkish military has had a special position of de facto veto player in the Turkish political system (for more on this, see Cizre, 2004: 113; Demirel, 2004; Gürbey, 1996: 12; Hale, 1994, 2003: 119; Jenkins, 2001; Kramer, 2000: 34; Narl1, 2000; Özbudun, 2000: 151; Rouleau, 2000: 102; Sakallığlu, 1997: 153). ${ }^{7}$ The past trajectory shows that the Turkish military has been heavily involved in civilian politics through various formal and informal channels and has interrupted the democratic processes four times in the Republican era (1960-1; 1971-3; 1980-3; 1997). It is also interesting that despite several interventions in politics, Turkish society views the military as the most trusted and prestigious institution in the country, which reinforces the civilians' sense of powerlessness vis-a-vis the military (Demirel, 2004). Given this political atmosphere and the military's harsh criticisms of the reform package, one would expect that the military would easily dominate civilians and resist the reform, which targeted its own political powers. However, the outcome of this conflictual situation was contrary to this military-dominated path in Turkish civil-military relations, which was perplexing.

\section{Understanding the puzzling outcome}

This is an interesting case of a bargaining situation because it involved a strongly prostatus quo veto player (the military). However, as shown above, the outcome of the bargaining process in this case was a new status quo, which was clearly beyond the lowest common denominator (the position of the veto player). This clearly shows that the rational hypothesis, which expects that if a veto player prefers the status quo to its alternative, then the status quo would be the outcome, does not hold in this case. Thus, with its focus on bargaining power and material interests, the rational model seems to remain limited in analyzing this bargaining situation.

It is clear that something happened during the bargaining process that created this unexpected outcome. Thus, we need to have a deeper look in order to have a better understanding of this puzzling outcome. Let us look at the bargaining process from the perspective of the argumentative model. Risse suggests two ways of knowing whether the power of the 'better argument' prevailed and persuasion took place during the bargaining process (2004: 302). The first test is looking at whether we can guess the bargaining outcome from the interests of the actors at the beginning of the process. If we find some surprises then we should have a look at factors other than the lowest common denominator. The second test is using process-tracing and looking at whether processes of persuasion actually took place leading to changes in actors' interests.

As indicated above, given the existence of a pro-status quo veto player in this case, the outcome of the bargaining process was surprising. Thus, this case passes the first test. However, it is difficult to argue that the process of persuasion took place and the 'better argument' won and led to such an outcome. The evidence for this is that the pro-status quo actor maintained its attitude even after changes took place. For instance, the military continued to believe that the MGK reform was unnecessary. Rather, the military argued that the MGK reform created a security vacuum in the sense that the reform eliminated certain powers of the most significant institution available to deal with Turkey's internal and external security problems. For instance, on one occasion, the Secretary-General of the MGK, Gen. Tuncer Kılınç, openly criticized the reform by stating: 
[This] reform package has rendered the MGK functionless. Political Islam and ethnic separatism [Kurdish separatism] remain serious threats. The appointment of a civilian secretary-general to that body would politicize it. One should not have weakened the MGK for the sake of democracy and the EU. (Quoted in Heper, 2005: 38)

The author's interviews with retired high-ranking military officials also support this observation. For instance, Ret. General Halit Edip Başer, former Deputy Chief of General Staff and former Commander of the Second Army, argued that the end of the Cold War did not reduce Turkey's threat perceptions because new threats emerged (e.g. the rise of political Islam, Kurdish separatism, crises in the Middle East, and instabilities in the Balkan and Caucasian regions). Therefore, Başer suggested that given this increased threat perception it was difficult to justify reforming the MGK, which played a vital role in national security. These give evidence strong enough to assert that the pro-status quo veto player was not really persuaded by the arguments of the pro-change actors. In other words, we do not see any evidence for the transformation of actors' interests or truthseeking behavior aimed at reasoned consensus during bargaining.

After showing the difficulties with the rationalist and discursive models in analyzing this puzzling case of bargaining, let us now turn to the normative hypothesis. The normative model would suggest that the pro-status quo veto player (the military) simply failed to block reforms during the bargaining stage because such an action would have caused significant damage to its ideational concerns (i.e. losing legitimacy, credibility, prestige in the public realm as a result of being an obstacle to Turkey's century-old Westernization process).

Since the late Ottoman period, the military elite in Turkey has been one of the strongest proponents of Westernization and modernization. The Turkish military views and presents itself as the guardian of secularism, democracy, and Westernization in Turkey. As a result, the Turkish military is considered the 'pioneer of Westernization and modernization,' the 'foremost modernizer' of Turkish society (Heper and Güney, 1996; Özbudun, 1966: 10). Joining the EU, for the military, is a significant step forward in finalizing Turkey's longterm Westernization efforts, which were initiated by the early republican bureaucratic-military elite (see Aydinlı et al., 2006). The military expressed its commitment to EU membership on several occasions. For instance, Gen. Yaşar Büyükanıt, former Chief of General Staff, expressed this commitment in the following way:

I state once again the views of the Turkish Armed Forces on this issue [Turkish-EU relations]: Turkish Armed Forces cannot be against the European Union because the European Union is the geo-political and geo-strategic ultimate condition for the realization of the target of modernization which Mustafa Kemal Atatürk chose for the Turkish nation. (Quoted in Kirişçi, 2005: 12; emphasis added)

Thus, Westernization (i.e. being part of modern Europe) is an important ideal, which constitutes the military's self-identity. Due to these constitutive ideals and the military's public statements about how much the military is committed to these ideals, the military found itself normatively entrapped during bargaining over the MGK reform (see also Sar1gil, 2007). This is because blocking the reform package, which was presented by the civilian government as an important step forward in Turkey's Westernization process, 
would mean acting against these shared ideals and this in turn would cause substantial damage to the military's prestige and credibility in society at a time when there was substantial support for EU membership in Turkey. As the past trajectory shows, Turkey's relations with the EU have had several ups and downs. As Canefe and Bora rightly observe, 'Turkey has a long history of opposing, admiring, copying, denying, naming, and judging things European' (2003: 134). However, the EU's Helsinki decision in 1999 was a 'turning point' in EU-Turkey relations (Öniş, 2003: 9; Uğur, 2003: 174) because this decision dramatically increased the credibility of the EU in the domestic realm (Uğur, 2003: 172). This also promoted optimism among Turks about the chances of Turkey joining the EU in the near future. Within this political environment, the vast majority of people supported Turkey's EU membership (see Figure 1).

Thus, given the military's strong support and commitment to EU membership in the past and the substantial public support for membership at that time (early 2000s), it would be quite difficult for the military to block such a crucial EU reform. The author's interviews with some retired high-ranking military officials also support this insight. For instance Retired General Tuncer Kılınç, former Secretary-General of the MGK (2001-3), stated to the author that:

Civilians [the government] presented the EU accession process and EU reforms as a matter of life and death, as something required by Turkey's long-term Westernization efforts. ... We know that the Turkish Armed Forces traditionally support Atatürk's goal of modernization and Westernization. Within such a situation, if the military blocked the reform [the MGK reform], the military would be held responsible for blocking Turkey's Westernization process. This concern led the military to comply with the reform process. ${ }^{8}$

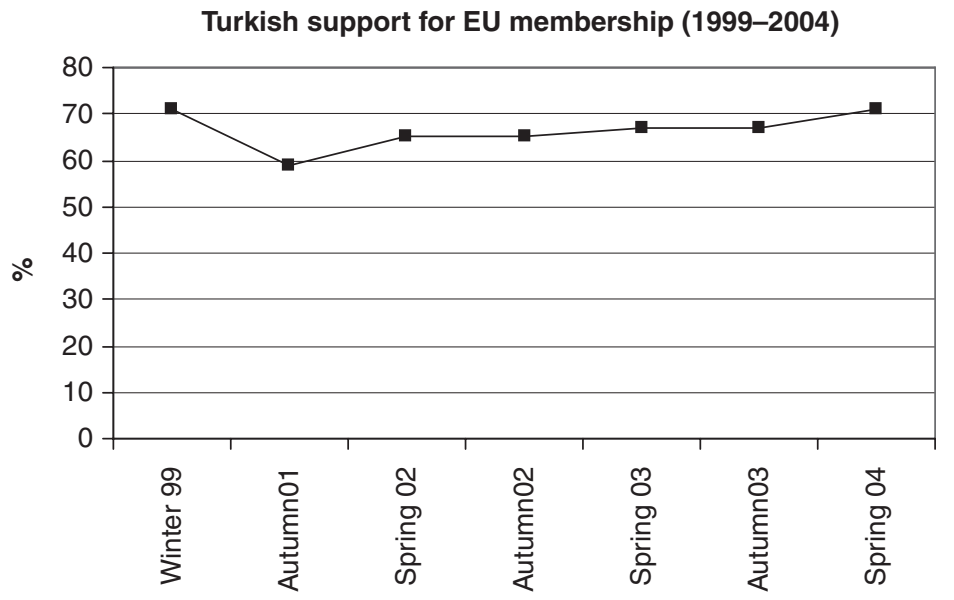

Figure I. Turkish public support for EU membership Source: Candidate Countries' Eurobarometer. 
Likewise, Ret. Gen. Halit Edip Başer, the former Deputy Chief of General Staff and former Commander of the Second Army (1998-2002), noted that:

The generals within the Turkish Armed Forces (TSK), who were also my close friends from the military schools and from the TSK, expressed their concerns, objections about the MGK reform to government several times. Despite this, the government pushed for the reform. Then the military had two options: To comply with the reform or to wake up early in the morning and do what is necessary [implying intervention]. The second option would damage the EU accession process and the military would be blamed as an obstacle to Turkey's further integration with the EU. Therefore, the military opted for the first option (i.e. acquiescing in the reform). ${ }^{9}$

Military experts also share this insight. For instance, columnist and writer Mehmet Ali Kışlalı, an expert on the Turkish military, stated to the author that:

Civilians [the AKP government] argued that they were following the path of Westernization opened by Kemal Atatürk, which has been strongly advocated by the military. They also argued that by objecting to reforms [the MGK reform], the military was preventing this process. The military was quite disturbed by these accusations and felt a need to express that the military was not against further integration with the EU. In the end, the military decided to be silent, and in particular the Chief of General Staff Gen. Hilmi Özkök (2002-06) decided not to object [to] these reforms. ${ }^{10}$

In brief, the military's involvement in civilian politics was in sharp contrast with the ideals of 'democracy' and 'Westernization,' which required civilian supremacy over the military. Thus, joining the EU necessitated curbing the political powers of the Turkish military, politically the most powerful military within NATO. Despite the fact that the military had expressed its strong commitment to Turkey's EU bid, which was regarded as a significant step forward within Turkey's Westernization and modernization process, it strongly criticized the EU reforms curbing its own powers. In other words, the generals were reluctant to give up their political powers for the sake of EU membership. In the end, however, they had to acquiesce with reforms. This is because blocking the reform package and sticking to the status quo would be perceived as being an obstacle to Turkey's century-old Westernization process and therefore as an 'inappropriate' or 'illegitimate' act by society. In other words, the generals found themselves normatively entrapped and this led to a new status quo in Turkish civil-military relations. ${ }^{11}$

\section{Conclusion}

To conclude, when we take each bargaining model individually, both the rational and argumentative models remain rather limited in explaining the unexpected outcome of bargaining processes on reforms in civil-military relations. The former model remains under-socialized due to its focus on the 'narrow utilitarian pursuit of [materially defined] self-interests' (Granovetter, 1985: 485). The latter one is over-socialized because the model exaggerates the level of truth- or consensus-seeking behavior and persuasion during bargaining situations. In the words of Johnston, 'The conditions [required for a successful communicative action] seem to be quite demanding, involving a high degree of 
prior trust, empathy, honesty, and power equality' (2001: 494). We should acknowledge that this is a rare situation in the political world. Furthermore, rather than transforming actors' identities and interests toward 'reasoned consensus' or 'common understanding,' communicative processes might even make divergences sharper. This is even more likely to happen when bargaining issues touch upon actors' core principles and values.

With its focus on actors' ideational concerns, the normative model appears to be more advantageous in analyzing bargaining situations in institutionalized settings. In such settings, norms, ideals, and values set the standards of legitimacy and so they not only structure the strategic interaction of instrumentally rational actors (regulative impact), but also shape the self-identification and legitimate interests and goals of actors (constitutive impact). Despite this, actors' ideational considerations (e.g. legitimacy, reputation) during bargaining in institutionalized settings have received little attention, especially in rational models. As Goddard observes, 'Bargaining theories often view legitimacy as epiphenomenal: actors may "legitimate" their actions, but this is little more than window dressing; at most, this process reveals information about interests and type but has no autonomous causal effect' (2006: 42). So, for a better understanding of bargaining processes in institutionalized settings, we should pay more attention to the impact of the social environment within which bargainers are embedded (Kramer et al., 1993: 634).

That having been said, a better strategy to get a full picture of bargaining processes in institutionalized settings would be employing a synthetic approach. This work does not claim that strategic considerations do not play any role in bargaining situations in institutionalized settings. However, rationality in such settings should be treated as context dependent (Wildavsky, 1992: 10). In other words, actors in institutionalized settings are 'socially' or 'normatively' rational beings. Therefore, the notion of 'interest' consists of two components in institutionalized settings: material and ideational. The former is shaped by actors' costbenefit calculations in terms of material utilities (power, security, welfare, etc.). The second component (ideational concerns such as recognition, legitimacy, reputation, high status, positive image, praise, etc.), on the other hand, is constituted by the social, normative context (norms, values, beliefs) in the institutional environment. Thus, we should understand bargaining in an institutionalized setting not only as strategic competition but also as a norm-guided social process.

A rationalist counter-argument, however, might suggest that those ideational concerns (legitimacy, credibility, prestige) might indeed be ideational but may also be interpreted as part of a rational process. In other words, complying with norms in a given institutional environment and acting appropriately to avoid certain costs (e.g. opprobrium) should be a very rational action. Then, actors' ideational concerns might be easily incorporated into a rational cost-benefit calculation (see Goldfarb and Griffith, 1991; Goertz and Diehl, 1992: 637; Noll and Weingast, 1991: 237). Schimmelfennig, for instance, states that 'the propagation and adoption of constitutive beliefs and practices institutionalized in the international system may be dictated by the states' self-interest - in an institutional environment, it can be the rational choice to behave appropriately' (2000: 116; emphasis added). Thus, the logic of appropriateness, a rationalist argument might assert, is not really different from the logic of consequentiality. ${ }^{12}$

There are, however, some problems with such reductionist arguments. As several others persuasively suggest, these two logics are intimately connected but they must be 
treated as distinctive (see Finnemore, 1996: 30; March and Olsen, 1998: 952) because the appropriateness logic derives from the social structures of collective understandings (e.g. norms, values), while the other is driven by instrumentally rational agents (Finnemore, 1996: 30). Therefore, it is difficult to incorporate these distinct factors and dynamics into a single framework (i.e. rational choice). Secondly, related to the first point, if we do not distinguish actors' normative and strategic considerations, then the rational model simply becomes non-falsifiable (see also Boland, 1981: 1034; Green and Shapiro, 1994). Since any behavior can be fitted into a framework of cost-benefit calculation or instrumental rationality, there would be no room for alternative explanations and this in turn would limit the explanatory power of theoretical models based on that rationality.

Since politics involves bargaining processes in almost every issue area, it has been one of the most studied political phenomena in the field and it is still worth continuing to spend ink on this issue. The case analyzed in this work also has major implications for the broader theoretical argument. First of all, as indicated above, ignoring their 'social' aspects, rational models tend to treat institutions as technical, contractual, and utilitarian formations. Due to such an understanding, the shadow of the future (i.e. the reciprocity function of institutionalized settings) is expected to reduce the chances of cooperation in bargaining processes in such settings, delaying agreement in hopes of getting a better deal. This study, however, clearly indicates that the shadow of the future might actually facilitate consensus formation, even in hard cases, where a veto player strictly prefers the status quo. The second point, related to the first one, is that, if bargaining in institutionalized settings involves both instrumental and non-instrumental factors and dynamics, then, instead of utilizing reductionist approaches, which tend to incorporate distinct factors and dynamics into a single framework, it would be more useful to employ synthetic approaches in analyzing such multidimensional processes. The case, furthermore, implies that norm promotion or creation might facilitate consensus formation among bargaining parties to long-term conflict.

\section{Acknowledgements}

I would like to thank Stacy Bondanella, Ole Elgström, B. Guy Peters, Frank Schimmelfennig, Daniel C. Thomas, two anonymous reviewers, and the journal editors for their very helpful comments and suggestions on earlier versions of the article.

\section{Notes}

1. I should also note that rather than treating them as mere descriptions or heuristics, this study considers these three models as distinct theoretical frameworks that draw attention to different factors and dynamics in a bargaining process.

2. One implication of this is that a normative context might facilitate cooperative behavior in bargaining situations (see Hopmann, 1995: 30; Kahneman et al., 1987: 649).

3. Risse argues that this is the main factor which distinguishes the discursive model from the other two. For Risse, the rule-guided behavior conceptualized by March and Olsen (1989) includes not only the logic of appropriateness (i.e. actors unconsciously follow taken-for-granted norms) but also the logic of truth-seeking or arguing (i.e. actors 'argue' to figure out the situation in which they act, apply the appropriate norm, or choose among conflicting rules) (2000: 6). Risse, however, suggests that the communicative model (based on the logic of arguing) is different from the normative and rational models because the rule-guided behavior (logic of appropriateness) 
and utility-maximization (logic of consequences) are both strategic actions, while communicative action (logic of arguing) represents non-strategic behavior in the sense that the goal is not to attain one's fixed preferences, but to seek a reasoned consensus (2000: 7). However, as will be discussed in the conclusion section, the author does not agree with such categorization (i.e. labeling both the logic of appropriateness and the logic of consequences as strategic behavior).

4. In October 2004, the Commission concluded that Turkey satisfied the Copenhagen political criteria and recommended that European leaders open accession negotiations with Turkey the following year. Following this recommendation, the EU began accession negotiations with Turkey in October 2005.

5. In order to assess the validity of certain insights, I conducted interviews with some retired generals such as Ret. Gen. Kenan Evren, Ret. Gen. Halit Edip Başer, Ret. Gen. Tuncer Kılınç, Ret. Maj. Gen. Rıza Küçükoğlu, Ret. Maj. Gen. Armağan Kuloğlu, and Ret. Military Judge Sadi Çaycı. These generals had occupied top positions within the military. More importantly, some of them held key positions during debates on the MGK reform (e.g. Gen. Tuncer Kilınç, the Secretary-General of the MGK; Gen. Halit Edip Başer, the Deputy Chief of General Staff). Thus, they were quite useful informants for the researcher in this study. Interviews were conducted in Ankara, Istanbul, and Bodrum, in July 2005 and in June-August 2006.

6. The statements of Ret. Gen. Kenan Evren, Ret. Gen. Halit Edip Başer, and Ret. Gen. Tuncer Kilınç, in particular, support this observation.

7. Some argue that, because of this, the Turkish democracy should be labeled one type of 'military democracy' (see Salt, 1999).

8. Author's interview (Ankara, July 2006).

9. Author's interview in Istanbul, Turkey (July 2006). This point was also emphasized by Ret. Gen. Kenan Evren, Ret. Maj. Gen. Rıza Küçükoğlu, Ret. Maj. Gen. Armağan Kuloğlu, and Ret. Military Judge Sadi Çayc1.

10. Author's interview (Ankara, June 2006).

11. This study, however, does not argue that civilian control of the military is a completely resolved issue in the Turkish Republic. The military is still politically the most powerful military within NATO and thus continues to exert a significant degree of influence on civilian politics. For instance, one recent example of the military's attempt to shape civilian politics was its reaction in 2007 to a disputed vote in the Turkish Parliament on a presidential candidate. When the ruling AKP nominated Foreign Minister Abdullah Gül as its candidate for the presidency, the military regarded this as an act against secular principles. The military thought that Abdullah Gül, whose wife wears a headscarf, had roots in political Islam and that his presidency would damage secular values. As a reaction to his nomination, on 27 April 2007, the Office of the Chief of General Staff sent a harsh warning to the government from its 'website,' stating that 'The problem that emerged in the presidential election process is focused on arguments over secularism. The Turkish Armed Forces are concerned about the recent situation. It should not be forgotten that the Turkish Armed Forces are a party to those arguments, and absolute defender of secularism.... It will display its attitude and action openly and clearly whenever necessary.' However, given the past trajectory of civil-military relations in Turkey, the reform efforts since 1999 emerge as unprecedented events. Other than several institutional and legal changes, which have limited the political powers of the military to a certain extent, we also see increasing criticism in the public sphere of the military's attempts to shape civilian politics. Thus, it is certain that Turkish civil-military relations have been undergoing a transformation in the last 
couple of years and it would be interesting to watch how and to what extent the Republic will align relations between the civil and military authorities on the practice in EU member states.

12. Some others argue for the reverse, reducing the logic of consequentiality to the logic of appropriateness (see Müller, 2004: 396).

\section{References}

Adler E (1997) Seizing the middle ground: Constructivism and world politics. European Journal of International Relations 3: 319-363.

Ahmad F (1993) The Making of Modern Turkey. London and New York: Routledge.

Avant D (2000) From mercenary to citizen armies: Explaining change in the practice of war. International Organization 54(1): 41-72.

Axelrod R (1984) The Evolution of Cooperation. New York: Basic Books.

Aydin S, Keyman EF (2004) European integration and the transformation of Turkish democracy. EU-Turkey Working Papers, No 2.

Aydınlı E, Özcan AN, and Akyaz D (2006) The Turkish military's march toward Europe. Foreign Affairs January/ February: 77-91.

Barnett M (1998) Dialogues in Arab Politics: Negotiations in Regional Order. New York: Columbia University Press.

Bazerman MH, Neale MA (1992) Negotiating Rationally. New York: The Free Press.

Bjurulf B, Elgström O (2005) Negotiating transparency: The role of institutions. In: Elgström $\mathrm{O}$ and Jönsson C (eds) European Union Negotiations: Processes, Network and Institutions. London and New York: Routledge, 45-63.

Boland LA (1981) On the futility of criticizing the neoclassical maximization hypothesis. American Economic Review 71(5): 1031-1036.

Brams SJ (1990) Negotiation Games: Applying Game Theory to Bargaining and Arbitration. New York: Routledge.

Canefe N, Bora T (2003) Intellectual roots of anti-European sentiments in Turkish politics: The case of radical Turkish nationalism. Turkish Studies 4(1): 127-148.

Checkel JT (1997) International norms and domestic politics: Bridging the rationalist-constructivist divide. European Journal of International Relations 3(4): 473-495.

Cizre Ü (2004) Problems of democratic governance of civil-military relations in Turkey and the European Union enlargement zone. European Journal of Political Research 43: 107-125.

Coşar S, Özman A (2004) Centre-right politics in Turkey after the November 2002 general election: Neoliberalism with a Muslim face. Contemporary Politics 10(1): 57-74.

Demirel T (2003) The Turkish military's decision to intervene: 12 September 1980. Armed Forces and Society 29(2): 253-280.

Demirel T (2004) Soldiers and civilians: The dilemma of Turkish democracy. Middle Eastern Studies 40(1): 127-150.

Diez T (2005) Turkey, the European Union and security complexes revisited. Mediterranean Politics 10(2): 167-180.

Doron G, Sened I (2001) Political Bargaining: Theory, Practice and Process. London and Thousand Oaks, CA: Sage Publications.

Elgström O (2005) The Cotonou agreement: Asymmetric negotiations and the impact of norms. In: Elgström O and Jönsson C (eds) European Union Negotiations: Processes, Network and Institutions. London and New York: Routledge, 183-200. 
Elgström O, Jönsson C (2000) Negotiation in the European Union: Bargaining or problem-solving? Journal of European Public Policy (Special Issue) 7(5): 684-704.

Elgström O, Smith M (2000) Introduction: Negotiation and policy-making in the European Union processes, system and order. Journal of European Public Policy 7(5): 673-683.

Elster J (1991) Arguing and Bargaining in Two Constituent Assemblies. The Storr Lectures, New Haven, CT: Yale Law School.

Ensminger J, Knight J (1997) Changing social norms: Common property, bridewealth, and clan exogamy. Current Anthropology 38(1): 1-24.

Ensminger J, Knight J (1998) Conflict over changing social norms: Bargaining, ideology, and enforcement. In: Brintan MC and Nee V (eds) The New Institutionalism in Sociology. New York: Russel Sage Foundation, 105-127.

Fearon J (1994) Domestic political audiences and the escalation of international disputes. American Political Science Review 88(3): 577-592.

Fearon J (1998) Bargaining, enforcement and international cooperation. International Organization 52(2): 269-305.

Finnemore M (1996) National Interests in International Society. Ithaca, NY: Cornell University Press.

Finnemore M, Sikkink K (1998) International norm dynamics and political change. International Organization 52(4): 887-917.

Fisher R, Ury W, and Patton B (1991) Getting to Yes: Negotiating Agreement without Giving In. New York: Penguin Books.

Goddard SE (2006) Uncommon ground: indivisible territory and the politics of legitimacy. International Organization 60(Winter): 35-68.

Goertz G, Diehl PF (1992) Toward a theory of international norms: Some conceptual and measurement issues. Journal of Conflict Resolution 36(December): 634-664.

Goffman E (1969) Strategic Interaction. Philadelphia, PA: University of Pennsylvania Press.

Goldfarb RS, Griffith WB (1991) Amending the economist's rational egoist model to include moral values and norms, part 2: Alternative solution. In: Koford KJ, Miller JB (eds) Social Norms and Economic Institutions. Ann Arbor, MI: University of Michigan Press, 39-59.

Granovetter M (1985) Economic action and social structure: The problem of embeddedness. The American Journal of Sociology 91(3): 481-510.

Green DP, Shapiro I (1994) Pathologies of Rational Choice Theory: A Critique of Applications in Political Science. New Haven, CT: Yale University Press.

Güney A, Karatekelioğlu P (2005) Turkey's EU candidacy and civil-military relations: Challenges and prospects. Armed Forces and Society 31(3): 439-462.

Gürbey G (1996) The Kurdish nationalist movement in Turkey since the 1980s. In: Olson R (ed.) The Kurdish Nationalist Movement in the 1990s: Its Impact on Turkey and the Middle East. Lexington, KY: University Press of Kentucky, 9-38.

Hale W (1994) Turkish Politics and the Military. London and New York: Routledge.

Hale W (2003) Human rights, the European Union and the Turkish accession process. Turkish Studies 4(1): 107-126.

Hall JA (1993) Ideas and the social sciences. In: Goldstein J, Keohane RO (eds) Ideas and Foreign Policy: Beliefs, Institutions and Political Change. Ithaca, NY and London: Cornell University Press, 31-57. 
Harris SG (1988) The role of the military in Turkey in the 1980s: Guardians or decision-makers? In: Heper M, Evin A (eds) State, Democracy and the Military Turkey in the 1980s. New York: Walter deGruyter, 177-201.

Heper M (2005) The European Union, the Turkish military and democracy. South European Society and Politics 10(1): 33-44.

Heper M, Güney A (1996) The military and democracy in the Third Turkish Republic. Armed Forces and Society 22(4): 619-642.

Heper M, Güney A (2000) The military and the consolidation of democracy: The recent Turkish experience. Armed Forces and Society 26(4): 635-657.

Høgsnes G (1989) Wage bargaining and norms of fairness - a theoretical framework for analyzing the norwegian wage formation. Acta Sociologica 32: 339-357.

Hopmann PT (1995) Two paradigms of negotiation: Bargaining and problem solving. Annals of the American Academy of Political and Social Science 542: 24-47.

Iklé FC (1964) How Nations Negotiate. New York: Praeger.

Jenkins G (2001) Context and Circumstance: The Turkish Military and Politics. Adelphi Paper 337. Oxford and New York: Oxford University Press.

Joerges C, Neyer J (1997) From intergovernmental bargaining to deliberative political processes: The constitutionalisation of comitology. European Law Journal 3(3): 273-299.

Johnston AI (2001) Treating international institutions as social environments. International Studies Quarterly 45: 487-515.

Jönsson C (1990) Communication in International Bargaining. London: Pinter.

Jönsson C, Elgström O (2005) Introduction. In: Elgström O and Jönsson C (eds) European Union Negotiations: Processes, Network and Institutions. London and New York: Routledge, 1-11.

Kahneman DJ, Knetsch JL, and Thaler RH (1987) Fairness as a constraint on profit seeking: Entitlements in the market. American Economic Review 76(4): 728-741.

Katzenstein PJ (1996) Introduction: Alternative perspectives on national security. In: Katzenstein PJ (ed.) The Culture of National Security: Norms and Identity in World Politics. New York: Columbia University Press, $1-7$.

Kirişçi K (2005) Turkey and the European Union: The domestic politics of negotiating preaccession. Macalester International Journal 15. Available at: http://www.edam.org.tr/ images/PDF/yayinlar/makaleler/Kirisci1.pdf (accessed 7 September 2009).

Klotz A (1995) Norms in International Relations: The Struggle against Apartheid. Ithaca, NY and London: Cornell University Press.

Knight J (1992) Institutions and Social Conflict. Cambridge: Cambridge University Press.

Knight J, Sened I (2001) Explaining Social Institutions. Ann Arbor, MI: University of Michigan Press. Kramer H (2000) A Changing Turkey: The Challenge to Europe and the United States. Washington, DC: Brookings Institution Press.

Kramer RM, Messick D (eds) (1995) Negotiation as a Social Process. Thousand Oaks, CA: Sage Publications.

Kramer RM, Pommerenke P, and Newton E (1993) The social context of negotiation: Effects of social identity and interpersonal accountability on negotiator decision making. The Journal of Conflict Resolution 37(4): 633-654.

Kubicek P (2005) The European Union and grassroots democratization in Turkey. Turkish Studies 6(3): 361-377. 
Lewis J (1998) Is the 'hard bargaining' image of the council misleading? The Committee of Permanent Representatives and the Local Elections Directive. Journal of Common Market Studies 36(4): 479-504.

Lewis J (2003) Institutional environments and everyday EU decision making: Rationalist or constructivist? Comparative Political Studies 36(1/2): 97-124.

Magen AA (2003) EU membership conditionality and democratization in Turkey: The abolition of the death penalty as a case study. Master's Thesis, Stanford Law School, J.S.M. (SPILS). Available at: http://law-stage.stanford.edu/publications/dissertations_theses/diss/Magen Amichai2003.pdf (accessed 22 January 2007).

March JG, Olsen JP (1989) Rediscovering Institutions. New York: Free Press.

March JG, Olsen JP (1998) The institutional dynamics of international political orders. International Organization 52(4): 943-969.

Moravcsik A (1993) Preferences and power in the European Community: A liberal intergovernmentalist approach. Journal of Common Market Studies 31(4): 473-524.

Moustakis F, Chaudhuri R (2005) Turkish-Kurdish relations and the European Union: An unprecedented shift in the Kemalist paradigm. Mediterranean Quarterly 16(4): 77-89.

Müftüler-Baç M (2005) Turkey's political reforms and the impact of the EU. South European Society and Politics 10(1): 17-31.

Müller H (2004) Arguing, bargaining and all that: Communicative action, rationalist theory and the logic of appropriateness in international relations. European Journal of International Relations 10(3): 395-435.

Narl1 N (2000) Civil-military relations in Turkey. Turkish Studies 1(1): 107-127.

Noll RG, Weingast BR (1991) Rational actor theory, social norms, and policy implementation. In: Monroe KR (ed.) The Economic Approach to Politics. New York: HarperCollins, 237-258.

Öniş Z (2003) Domestic politics, international norms and challenges to the state: Turkey-EU relations in the post-Helsinki era. Turkish Studies 4(1): 9-34.

Öniş Z, Yılmaz S (2005) Turkey-EU-US triangle in perspective: Transformation or continuity? Middle East Journal 59(2): 265-284.

Oran B (2005) Türkiye'de Azınlıklar: Kavramlar, Teori, Lozan, İç Mevzuat, İçtihat, Uygulam (Minorities in Turkey: Concepts, Theory, Lozan, Domestic Law and Application). İstanbul: İletişim.

Özbudun E (1966) The role of the military in recent Turkish politics. Occasional Papers in International Affairs 14, Center for International Affairs, Harvard University.

Özbudun E (2000) Contemporary Turkish Politics: Challenges to Democratic Consolidation. Boulder, $\mathrm{CO}$ and London: Lynne Rienner Publishers.

Putnam R (1988) Diplomacy and domestic politics: The logic of two-level games. International Organization 42(3): 427-460.

Riker WH (1962) The Theory of Political Coalitions. New Haven, CT and London: Yale University Press.

Risse T (1999) International norms and domestic change: Arguing and communicative behavior in the human rights area. Politics and Society 27: 529-559.

Risse T (2000) 'Let's argue!': Communicative action in world politics. International Organization 54(1): 1-39.

Risse T (2004) Global governance and communicative action. Government and Opposition 39(2): 288-313.

Rouleau E (2000) Turkey's dream of democracy. Foreign Affairs 79(6): 100-114. 
Sakallığlu ÜC (1997) The anatomy of Turkish military's political autonomy. Comparative Politics 29(2): 151-166.

Salmoni BA (2003) Turkey's summer 2003 legislative reforms: EU avalanche, civil-military revolution, or Islamist assertion? Strategic Insight, Center for Contemporary Conflict, National Security Affairs Department, Naval Postgraduate School, Monterey, CA, 2 September.

Salt J (1999) Turkey's military democracy. Current History 98(625): 72-78.

Sarigil Z (2007) Europeanization as institutional change: The case of Turkish military. Mediterranean Politics 12(1): 39-57.

Scharpf FW (1988) The joint-decision trap: Lessons from German federalism and European integration. Public Administration 66(3): 239-278.

Schelling T (1963) The Strategy of Conflict. New York: Oxford University Press.

Schimmelfennig F (2000) International socialization in the new Europe: Rational action in an institutional environment. European Journal of International Relations 6(1): 109-138.

Schoppa LJ (1999) The social context in coercive international bargaining. International Organization 53(2): 307-342.

Tocci N (2005) Europeanization in Turkey: Trigger or anchor for reform? South European Society and Politics 10(1): 73-83.

Tsebelis G (2002) Veto Players: How Political Institutions Work. Princeton, NJ: Princeton University Press.

Uğur M (2003) Testing times in EU-Turkey relations: The road to Copenhagen and beyond. Journal of Southern Europe and the Balkans 5(2): 165-183.

Vardar D (2005) European Union-Turkish relations and the question of citizenship. In: Keyman EF, İçduygu A (eds) Citizenship in a Global World: European Questions and Turkish Experiences. London and New York: Routledge Taylor and Francis Group, 87-102.

Walton RE, McKersie RB (1965) A Behavioral Theory of Labor Negotiations. New York: McGraw-Hill.

Wendt A (1999) Social Theory of International Politics. New York: Cambridge University Press.

Wildavsky A (1992) Indispensable framework or just another ideology?: Prisoner's dilemma as an anti-hierarchical game. Rationality and Society 4(January): 8-23.

\section{Biographical note}

Zeki Sarigil is Assistant Professor at the Department of Political Science, Bilkent University, Turkey. His research interests include institutional theory, institutional change, civil-military relations, ethno-nationalism, and foreign policy. He has previously published in journals such as Armed Forces \& Society, Critical Policy Studies, Ethnic and Racial Studies, and Mediterranean Politics. 